\title{
Effect of administration of recombinant bovine somatotropin on health and performance of lactating dairy cows diagnosed with hyperketonemia
}

\author{
K. Gohary,* K. E. Leslie, ${ }^{*}$ J. Ford, ${ }^{*}$ M. Capel,† S. J. LeBlanc, ${ }^{*}$ and T. F. Duffield ${ }^{* 1}$ \\ *Department of Population Medicine, Ontario Veterinary College, University of Guelph, Guelph, Ontario, N1G 2W1, Canada \\ †Perry Veterinary Clinic, Perry, NY 14530
}

\begin{abstract}
The effect of administering recombinant bovine somatotropin (rbST) to cows with hyperketonemia during the early postpartum period on health, metabolic parameters, milk production, and early reproductive performance was evaluated in a double-blinded clinical trial. Cows from 8 dairy herds in New York State were tested weekly between 3 and $16 \mathrm{~d}$ in milk for elevated serum $\beta$-hydroxybutyrate. Cows were enrolled in the study when blood $\beta$-hydroxybutyrate was $\geq 1.3$ $\mathrm{mmol} / \mathrm{L}$ for the first time. Enrolled cows were randomly assigned to a treatment $(\mathrm{n}=273)$ or placebo control $(\mathrm{n}=270)$ group. Treated cows were given 325 mg of rbST subcutaneously on the day of enrollment and again $14 \mathrm{~d}$ later. Control cows received the same regimen except the syringe contained only the carrier without somatotropin. After enrollment, blood samples were collected weekly for $4 \mathrm{wk}$ and submitted to the laboratory to be analyzed for selected metabolites. Risk ratios for clinical diseases subsequent to treatment were calculated using Poisson regression. Continuous data were analyzed using linear mixed models. Time to first insemination was assessed with survival analysis. In the $42 \mathrm{~d}$ following the first administration of rbST, incidence risks of displaced abomasum, clinical ketosis, metritis, clinical mastitis, and lameness were not different between treatment groups. Cows treated with rbST had a slightly lower body condition score $28 \mathrm{~d}$ after enrollment compared with control cows. In the $4 \mathrm{wk}$ following enrollment, serum nonesterified fatty acids and aspartate amino-transferase were slightly higher for treated than control cows, respectively. Serum glucose, calcium, haptoglobin, and $\beta$-hydroxybutyrate were similar between groups. Treatment had no effect on resolution of hyperketonemia in any of the $4 \mathrm{wk}$ after enrollment. Milk production in either of the 2-wk
\end{abstract}

Received April 14, 2014.

Accepted March 25, 2015

${ }^{1}$ Corresponding author: tduffiel@uoguelph.ca periods after each treatment was not different between treated and control cows. Furthermore, milk production was not different between groups from enrollment to $98 \mathrm{~d}$ in milk $(42.6 \pm 0.6$ and $42.1 \pm 0.7 \mathrm{~kg} / \mathrm{d}$ for treatment and control groups, respectively). Treatment had no effect on time to first insemination (83 and $74 \mathrm{~d}$ in milk for treatment and control groups, respectively; hazard ratio $=0.72$ ) or first insemination pregnancy risk (27 and 29\% for treatment and control groups, respectively; risk ratio $=0.92$ ). Based on the current results, it is not recommended to use a low dose of rbST as therapy for cows with hyperketonemia.

Key words: dairy cow, hyperketonemia, ketosis treatment, recombinant bovine somatotropin

\section{INTRODUCTION}

Essentially all dairy cows go through a period of negative energy balance, decreased DMI, insulin resistance, and immune suppression around the time of calving. The ability to adapt to these changes is part of what separates cows that remain healthy from those that develop metabolic or infectious diseases associated with early lactation (LeBlanc, 2010). One of the important metabolic problems in early-lactation dairy cows is hyperketonemia. Hyperketonemia in lactating dairy cows is defined as an elevated concentration of ketone bodies in the blood, which may or may not be accompanied by clinical signs (Andersson, 1988; Kelton et al., 1998), but is associated with decreased production and impaired reproduction and health measures (Duffield et al., 2009; Ospina et al., 2010; McArt et al., 2011), resulting in significant economic effects. A lack of gluconeogenic substrates is thought to contribute to hyperketonemia; therefore, many therapies for hyperketonemia target the provision of glucogenic substrates. The plethora of physiological, environmental, and genetic factors that interact to cause a cow to become hyperketonemic can make it difficult to determine the best method of treatment because this may vary depending on herd and cow-level factors. However, a considerable amount of work has been done to try to identify effective treatments as well as preventative measures to mitigate 
the negative effects of hyperketonemia (Duffield et al., 1998; McArt et al., 2011; Gordon et al., 2013).

Some studies have shown that administration of recombinant bST (rbST) during the late dry period may have beneficial effects on metabolic diseases. Prepartum rbST treatment decreased prepartum plasma concentrations of NEFA and BHBA (Putnam et al., 1999). Similarly, rbST administered during the transition period (both before and following calving) resulted in some positive effects such as increased BW and BCS (Gulay et al., 2000, 2003). Increased DMI by cows treated with $\mathrm{rbST}$ in the transition period has also been documented in a few studies (Gulay et al., 2000, 2004a), and this is likely the mechanism through which increased BW and BCS would occur. These authors hypothesized that the increased body condition and BW may help cows to cope better with negative energy balance during the transition period.

Bovine somatotropin can positively influence glucose metabolism by increasing hepatic gluconeogenesis, reducing glucose oxidation, and increasing glycogen mobilization; all actions combined result in an increase of blood glucose concentrations (Peel and Bauman, 1987; Bauman et al., 1989). When cows diagnosed with left displacement of the abomasum were treated with $500 \mathrm{mg}$ of rbST immediately after surgical correction, blood glucose increased and urine ketones were reduced (Fetrow et al., 1999). Therefore, administration of rbST to cows with hyperketonemia may increase blood glucose and reduce fat mobilization and so might be useful as a treatment for hyperketonemia.

The objective of this study was to evaluate the effect of administration of 2 doses of $325 \mathrm{mg}$ of sometribove zinc to lactating dairy cows diagnosed with hyperketonemia on milk production in early lactation, early reproductive performance, and health and metabolic parameters.

\section{MATERIALS AND METHODS}

\section{Study Population}

The study population was a convenience sample (herds with good record-keeping practices, proximity to the investigators, and willingness to participate in the study) of Holstein cows of all parities from 8 herds in New York State. Farms ranged in size from 624 to 1,600 milking cows, with an average herd size of approximately 1,000 milking animals. Facilities were freestall design, and animals were fed a TMR representative of commercial rations formulated to meet NRC requirements. All farms used the farm management program DairyComp 305 (Valley Agricultural Software, Tulare,
CA). Animals were excluded if they were not clinically healthy at the time of enrollment or if they had a displaced abomasum, metritis, or severe clinical mastitis in the current lactation before being enrolled. Data were collected from April 14, 2010, until September 27, 2011. The Animal Care Committee at the University of Guelph approved the Animal Utilization Protocol (AUP number: 10R008) before the trial was started.

\section{Data Collection and Study Design}

Lactating cows of all parities between 3 and 16 DIM, inclusive, were screened once a week for blood BHBA concentration $\geq 1.3 \mathrm{mmol} / \mathrm{L}$ using a validated pointof-care meter (Precision Xtra; Abbott Diabetes Care Canada Inc., Mississauga, ON, Canada). Cows were enrolled in the study when blood BHBA concentration was $\geq 1.3 \mathrm{mmol} / \mathrm{L}$ for the first time. Cows enrolled in the study were blocked by herd and parity group and were sequentially randomized to the treatment group to receive $325 \mathrm{mg}$ of sometribove zinc suspension (Posilac; Elanco Animal Health, A Division of Eli Lilly and Co., Greenfield, IN) or the control group to receive placebo injections with carrier (no sometribove) based on predetermined random number tables. The dose of rbST used in this trial was an average of doses used in studies done previously that provided evidence of positive outcomes when rbST was administered at a dose between 143 to $500 \mathrm{mg}$ (Putnam et al., 1999; Gulay et al., 2007). Cows were injected twice, $14 \mathrm{~d}$ apart, at the depression on either side of the tail head. All trial staff were blinded to the identity of the treatments until statistical analysis was completed.

In addition to the blood sample obtained at the time of enrollment, 4 blood samples were obtained from the coccygeal vessels on d 7, 14, 21, and 28 after enrollment with a $10-\mathrm{mL}$ vacuum tube containing no anticoagulant. Blood samples were allowed to clot at room temperature for approximately $1 \mathrm{~h}$, then were stored in a cooler and transported to a local veterinary clinic for processing within $6 \mathrm{~h}$. Blood was centrifuged at $1,200 \times g$ at $20^{\circ} \mathrm{C}$ for $10 \mathrm{~min}$, and serum was separated and frozen at $-20^{\circ} \mathrm{C}$ before submission to the Animal Health Laboratory at the University of Guelph for analysis of BHBA, glucose, NEFA, total calcium, aspartate amino-transferase (AST), and haptoglobin using a Roche Cobas 6000 c501 automated chemistry analyzer (Roche Canada, Laval, Quebec). Test reagents for glucose, calcium, and AST were supplied by Roche diagnostics (Indianapolis, IN) and for BHBA and NEFA, Randox Laboratories (UK). They were prepared by the Animal Health Laboratory staff to measure haptoglobin. 
Further data collection included BCS at the time of enrollment and on d 28 after enrollment. Body condition score was assigned by one research technician throughout the study. Disease data were collected until $42 \mathrm{~d}$ after enrollment and daily milk weights for 98 d after enrollment. Daily farm treatment records were collected weekly from each farm, as well as daily milk printouts for all cows on the trial. Weekly backups were obtained from DairyComp 305 (Valley Agricultural Software). Dates of the first insemination after calving and first-insemination pregnancy diagnoses were recorded in DairyComp 305.

\section{Statistical Analyses}

Data were analyzed using SAS (V. 9.3., SAS institute Inc., Cary, NC) unless specified otherwise. Variables considered for inclusion in each statistical model were treatment as the main effect and fixed effects of farm; parity $(1,2$, or $\geq 3$ ); season of calving (summer, fall, winter, or spring); BCS at enrollment in the study (categorized as $\leq 2.5,2.75$ to 3.5 , and $\geq 3.75$ ); DIM at enrollment in the trial (categorized as 3 to 9 DIM or 10 to 16 DIM); calving ease (categorized as no assistance, easy pull, and dystocia); and whether the cow had twins, retained placenta, or milk fever. The full model with all variables included was fitted. Nonsignificant variables $(P \geq 0.05)$ were removed from the model in a backward step-wise elimination process, if the variable had no confounding effect on treatment (assessed by a change of $20 \%$ in the coefficient of treatment when the model was run with and without the potential confounder). Remaining variables in the model were assessed for a significant interaction with treatment one at a time.

To account for repeated measures within a cow while fitting any of the linear mixed models, various correlation structures (Unstructured, Autoregressive1, AutoregressiveH1, Toeplitz, ToeplitzH, and Compound symmetry) were tested. The model with the correlation structure that resulted in the smallest Akaike information criterion, indicating the best fit, was chosen for the final modeling process.

For all of the linear mixed models, graphical assessment of model fit was performed by plotting residuals against predicted values to identify outliers and assess the homogeneity of variance. Residuals were plotted in a histogram to assess the assumption of normality. If required, a $\log$ or square-root transformation of the dependent variable was performed to achieve a normal distribution of residuals, and then the model results were back-transformed for interpretation. For the survival analysis model, the assumption of proportionality was assessed by including a time-dependent covariate (an interaction between the covariate and the logarithm of the time at risk) within the model. The time-dependent variable was kept in the model if the assumption was violated (Dohoo et al., 2009).

Health. Risk ratios and $95 \%$ confidence intervals comparing disease incidence risk between treatment groups were calculated using $2 \times 2$ contingency tables using Epi Info 6 software package (Centers for Disease Control and Prevention, Atlanta, GA). $P$-values were calculated using a chi-squared test. In cases where individual cell expected frequencies were below 5, Fisher's exact test was employed. Further analysis for any disease associated with treatment with a $P$-value $<0.2$ was performed using a Poisson regression analysis that accounted for overdispersion (Ospina et al., 2012). Poisson regression was performed to compare the incidence of death or euthanasia and clinical mastitis between the treatment and control groups using the GENMOD procedure in SAS (V. 9.3., SAS institute Inc.). Body condition score at $28 \mathrm{~d}$ after enrollment was compared between the treated and control groups using a linear regression model with the MIXED procedure.

Blood Analytes. For each of the serum metabolites, a linear mixed model accounting for repeated measures was fitted using the MIXED procedure in SAS. Further analysis was performed on serum BHBA concentrations to evaluate resolution of hyperketonemia between the treatment and control groups at each of the first, second, third, and fourth week after enrollment. Twoby-two contingency tables using the Epi Info 6 software package (Centers for Disease Control and Prevention) were constructed, and risk ratios (RR), $P$-values, and 95\% confidence intervals were calculated using a chisquared test. Poisson regression analysis was warranted if at a given week, treatment was associated with resolution of hyperketonemia (BHBA $<1.3 \mathrm{mmol} / \mathrm{L}$ ) with $P<0.2$.

Milk Production. Daily milk weights were averaged into weekly weights. A linear mixed model with cow included as a repeated measure was built using the MIXED procedure in SAS. The correlation structure with the lowest Akaike information criterion was used to continue the model-building process. Statistical interaction of the effect of treatment with time (week) was formally tested; however, the effect of treatment on milk yield in each of the 2-wk periods after each treatment was also examined regardless of the treatment-time interaction term because of the expected duration of action of rbST.

Reproduction. The time from calving to first insemination and the probability of pregnancy to first insemination (conception risk) were compared between treatment groups using survival analysis and a Poisson regression model, respectively. Cows that were not inseminated and cows that were inseminated but the 
outcome was not known were retained in the analysis with the pregnancy status designated as censored. The survival analysis model was fitted using Cox's proportional hazard regression (the PHREG procedure in SAS), and the Poisson regression model was fitted using the GENMOD procedure and accounted for overdispersion.

\section{RESULTS}

Based on sample-size calculations to provide power of 80 and $5 \%$ allowable error to detect a reduction in the incidence of displaced abomasum from 9 to $4.5 \%$, and a $2-\mathrm{kg} / \mathrm{d}$ increase in milk production in cows with hyperketonemia treated with rbST, a total of 1,088 cows were enrolled in this study. However, unexplained discrepancies existed in BHBA measurement between the meter used to screen cows for enrollment in the study and results from the laboratory to confirm the enrolment criterion (mean BHBA $=2.0 \pm 0.03$ and 1.6 $\pm 0.03 \mathrm{mmol} / \mathrm{L}$ for the meter and laboratory measurements, respectively). As a result of this discrepancy, data from 272 and 273 cows from the rbST treatment and control groups, respectively, were excluded from the analysis because their hyperketonemia status (BHBA $\geq 1.3 \mathrm{mmol} / \mathrm{L}$ ) was not confirmed. Of the cows that were excluded from the analysis, 219 had BHBA of 1.1 or $1.2 \mathrm{mmol} / \mathrm{L}$ and $326 \mathrm{had}$ BHBA $<1.1 \mathrm{mmol} / \mathrm{L}$ as measured in the laboratory. Therefore, data were analyzed for a total of 543 cows that were confirmed to be hyperketonemic based on laboratory testing of serum BHBA. For the cows remaining in the analysis, Table 1 compares parity as well as the incidence of health events occurring before enrollment in the study between the treatment and control groups.

\section{Health}

Table 2 summarizes cow removal and clinical disease incidence from enrollment to $42 \mathrm{~d}$ after enrollment for cows treated with rbST or placebo. Based on chisquared $P$-values further Poisson regression analysis was warranted for mortality $(P=0.03)$ and for clinical mastitis $(P=0.11)$. The final Poisson regression model for mortality (death and euthanasia) included treatment, calving ease, and farm. Accounting for these covariates, the risk of mortality tended to be higher for treated cows than control cows (8.5 and 3.9\%, respectively; $\mathrm{RR}=1.95,95 \% \mathrm{CI}: 0.96$ to $3.99, P=0.07)$. For clinical mastitis, the only variable that remained in the final model was treatment. The risk of developing clinical mastitis in the $28 \mathrm{~d}$ after initial treatment was not significantly different for treated and control cows (9.2 and $5.6 \%$, respectively; $\mathrm{RR}=1.65,95 \% \mathrm{CI}: 0.89$ to $3.1, P=0.11)$.

A $\log$ transformation of the dependent variable was required to analyze BCS at $28 \mathrm{~d}$ after enrollment. In addition to treatment, covariates in the model were season of calving and BCS at enrollment. Hyperketonemic cows that were treated with rbST had lower BCS $28 \mathrm{~d}$ after enrollment than cows in the control group [2.8 (95\% CI: 2.69 to 2.89) and 2.9 (95\% CI: 2.77 to 2.97), respectively; $P=0.04]$.

\section{Blood Analytes}

The correlation structure Unstructured was used to model all blood analytes except for calcium, for which the correlation structure ToeplitzH was used.

$\boldsymbol{N E F A . ~ A ~ l o g ~ t r a n s f o r m a t i o n ~ o f ~ t h e ~ d e p e n d e n t ~ v a r i - ~}$ able was required because of a nonnormal distribution.

Table 1. Description of cows and incidence of health events that occurred before enrollment and treatment with 2 doses of $325 \mathrm{mg}$ of recombinant bST (rbST) $14 \mathrm{~d}$ apart or placebo after diagnosis of hyperketonemia ${ }^{1}$

\begin{tabular}{|c|c|c|c|c|c|}
\hline \multirow[b]{2}{*}{ Item } & \multicolumn{2}{|c|}{$\operatorname{rbST}$} & \multicolumn{2}{|c|}{ Placebo (control) } & \multirow[b]{2}{*}{$P$-value } \\
\hline & $\%$ & No. & $\%$ & No. & \\
\hline Enrolled (total) & 50.3 & 273 & 49.7 & 270 & - \\
\hline Parity 1 & 19.8 & 54 & 25.2 & 68 & $0.13^{2}$ \\
\hline Parity 2 & 25.3 & 69 & 23.7 & 64 & $0.67^{2}$ \\
\hline Parity $\geq 3$ & 54.9 & 150 & 51.1 & 138 & $0.37^{2}$ \\
\hline Twins & 1.1 & 3 & 2.6 & 7 & $0.20^{3}$ \\
\hline Dystocia $^{4}$ & 26.0 & 71 & 21.9 & 59 & $0.26^{3}$ \\
\hline Retained placenta & 4.0 & 11 & 4.1 & 11 & $0.98^{3}$ \\
\hline Milk fever & 4.4 & 12 & 2.2 & 6 & $0.16^{3}$ \\
\hline
\end{tabular}

${ }^{1}$ Laboratory diagnosis based on serum BHBA $\geq 1.3 \mathrm{mmol} / \mathrm{L}$. All cows were tested once weekly between 3 and 16 DIM. Two doses of rbST were administered $2 \mathrm{wk}$ apart with the first dose administered between 3 and 16 DIM at the time of diagnosis of hyperketonemia.

${ }^{2}$ Calculated using a Z-test to compare 2 proportions.

${ }^{3}$ Calculated using a chi-squared test.

${ }^{4}$ Dystocia was defined as 2 or greater on a 5-point scale for ease of calving. 
Table 2. Cow removal (sold and dead) and clinical-disease incidence from enrollment to $42 \mathrm{~d}$ after enrollment for cows treated with 2 doses of $325 \mathrm{mg}$ of recombinant bST (rbST) $14 \mathrm{~d}$ apart or placebo after diagnosis of hyperketonemia ${ }^{1}$

\begin{tabular}{|c|c|c|c|c|c|c|c|}
\hline Item & \multicolumn{2}{|c|}{$\operatorname{rbST}$} & \multicolumn{2}{|c|}{ Placebo (control) } & $\mathrm{RR}^{2}$ & $95 \% \mathrm{CI}$ & $P$-value ${ }^{3}$ \\
\hline Died or euthanized & 8.5 & 22 & 3.9 & 10 & 2.15 & $1.04-4.45$ & 0.03 \\
\hline Displaced abomasum & 10.3 & 28 & 13.3 & 36 & 0.77 & $0.48-1.22$ & 0.27 \\
\hline Clinical ketosis & 5.1 & 14 & 6.3 & 17 & 0.81 & $0.41-1.62$ & 0.56 \\
\hline Metritis & 6.6 & 18 & 7.8 & 21 & 0.85 & $0.46-1.55$ & 0.59 \\
\hline
\end{tabular}

${ }^{1}$ Laboratory diagnosis based on serum BHBA $\geq 1.3 \mathrm{mmol} / \mathrm{L}$. All cows were tested once weekly between 3 and 16 DIM. Two doses of rbST were administered 2 wk apart with the first dose administered between 3 and 16 DIM at the time of diagnosis of hyperketonemia.

${ }^{2} \mathrm{RR}=$ risk ratio.

${ }^{3}$ Calculated using a chi-squared test.

In addition to treatment, variables retained in the final model were farm, parity, BCS at enrollment, DIM at enrollment, season of calving, and week of blood sampling. Over the $4 \mathrm{wk}$ following treatment, serum NEFA was higher for cows treated with rbST than cows treated with placebo $[0.50 \mathrm{mmol} / \mathrm{L}(95 \%$ CI: 0.46 to $0.55)$ and $0.47 \mathrm{mmol} / \mathrm{L}$ (95\% CI: 0.43 to 0.52$)$, respectively; $P=0.05]$.

BHBA and Hyperketonemia. Table 3 shows the $\mathrm{RR}$ for resolution of hyperketonemia in each of the 4 wk following initial treatment. Resolution of hyperketonemia was similar between the treatment and control groups.

For the mixed-model analysis, a log transformation of the BHBA concentration was required. In addition to treatment, variables retained in the final model were farm, parity, DIM at enrollment, calving ease, and week of blood sampling. Serum BHBA over the 4 wk following enrollment was not different between treated and control cows $[1.4 \mathrm{mmol} / \mathrm{L}$ (95\% CI: 1.30 to 1.46$)$ and
$1.3 \mathrm{mmol} / \mathrm{L}(95 \% \mathrm{CI}: 1.26$ to 1.42$)$, respectively; $P=$ $0.26]$.

Glucose. A square-root transformation of the dependent variable was required. In addition to treatment, variables retained in the model were farm, parity, season of calving, whether a cow had twins or not, and week of blood sampling. Serum glucose concentrations were similar between treatment and control groups [2.18 mmol/L (95\% CI: 2.05 to 2.31$)$ and $2.20 \mathrm{mmol} / \mathrm{L}$ (95\% CI: 2.07 to 2.33 ), respectively; $P=0.63$ ].

Aspartate Aminotransferase. A log transformation of the dependent variable was required. In addition to treatment, variables retained in the model were farm, DIM at enrollment, and week of blood sampling. Serum AST was higher for cows treated with rbST than control cows $[91 \mathrm{U} / \mathrm{L}(95 \% \mathrm{CI}: 87.4$ to 94.3$)$ and 87 U/L (95\% CI: 83.5 to 90.2 ), respectively; $P=0.03$ ].

Calcium. Transformation of the dependent variable was not required. In addition to treatment, variables retained in the model were farm, parity, DIM

Table 3. Resolution of hyperketonemia in the $4 \mathrm{wk}$ following initial treatment in cows treated with 2 doses of $325 \mathrm{mg}$ recombinant bST (rbST) $14 \mathrm{~d}$ apart or placebo after diagnosis of hyperketonemia ${ }^{1}$

\begin{tabular}{|c|c|c|c|c|c|c|c|}
\hline \multirow[b]{2}{*}{ Week $^{2}$} & \multicolumn{2}{|c|}{$\mathrm{rbST}$} & \multicolumn{2}{|c|}{ Placebo (control) } & \multirow[b]{2}{*}{$\mathrm{RR}^{3}$} & \multirow[b]{2}{*}{$95 \% \mathrm{CI}$} & \multirow[b]{2}{*}{$P$-value ${ }^{4}$} \\
\hline & No. ${ }^{5}$ & $\%$ & No. & $\%$ & & & \\
\hline 1 & 138 & 52.1 & 140 & 53.0 & 0.98 & $0.84-1.15$ & 0.83 \\
\hline 2 & 115 & 43.6 & 104 & 40.0 & 1.09 & $0.89-1.33$ & 0.41 \\
\hline 3 & 89 & 34.5 & 84 & 33.2 & 1.04 & $0.82-1.32$ & 0.76 \\
\hline 4 & 87 & 33.9 & 83 & 33.2 & 1.02 & $0.80-1.30$ & 0.88 \\
\hline
\end{tabular}

${ }^{1}$ Laboratory diagnosis based on serum BHBA $\geq 1.3 \mathrm{mmol} / \mathrm{L}$. All cows were tested once weekly between 3 and 16 DIM. Two doses of rbST were administered 2 wk apart with the first dose administered between 3 and 16 DIM at the time of diagnosis of hyperketonemia.

${ }^{2}$ Week after initial treatment.

${ }^{3} \mathrm{RR}=$ risk ratio.

${ }^{4}$ Calculated using a chi-squared test.

${ }^{5}$ Number of cows with serum BHBA $\geq 1.3 \mathrm{mmol} / \mathrm{L}$. 
at enrollment, season of calving, whether a cow had retained placenta or not, and week of blood sampling. Serum calcium was similar between treatment and control groups $[2.40 \mathrm{mmol} / \mathrm{L}$ (95\% CI: 2.36 to 2.45 ) and $2.38 \mathrm{mmol} / \mathrm{L}$ (95\% CI: 2.34 to 2.43 ), respectively; $P=0.09]$.

Haptoglobin. A log transformation was required because of a nonnormal distribution for the haptoglobin data. In addition to treatment, variables retained in the final model were farm, parity, DIM at enrollment, season of calving, milk-fever occurrence, and week of blood sampling. Serum haptoglobin concentrations were not different between treated and control cows $[0.16 \mathrm{~g} / \mathrm{L}$ (95\% CI: 0.13 to 0.20$)$ and $0.16 \mathrm{~g} / \mathrm{L}(95 \%$ CI: 0.13 to 0.19), respectively; $P=0.63$.

\section{Milk Production}

Seven cows were excluded because daily milk weights were not recorded, resulting in 536 cows included in the analysis. Transformation of the dependent variable was not required. The correlation structure Unstructured was used to model milk production. Variables retained in the final model were treatment, farm, parity, week of lactation, DIM at enrollment, season of calving, and calving ease. Overall, milk production to 98 DIM was not different between treatment and control groups $(42.6 \pm 0.63 \mathrm{~kg} / \mathrm{d}$ and $42.1 \pm 0.66 \mathrm{~kg} / \mathrm{d}$, respectively; $P=0.36$ ). Treatment and time (week) did not significantly interact, and treatment groups did not differ when the two 2-wk periods after each administration of treatment were assessed specifically $(30.9 \pm 1.49$ and $31.1 \pm 1.52 \mathrm{~kg} / \mathrm{d}, 35.2 \pm 1.22$ and $34.9 \pm 1.23 \mathrm{~kg} / \mathrm{d}$, $39.7 \pm 1.24$ and $39.2 \pm 1.23 \mathrm{~kg} / \mathrm{d}, 45.1 \pm 1.67$ and 44.9 $\pm 1.64 \mathrm{~kg} / \mathrm{d}$ for treatment and control groups, respectively, in wk 1 to $4 ; P=0.50$ to 0.84 ).

\section{Reproductive Performance}

For the survival analysis model, treatment and farm were the only variables retained in the model. The assumption of proportionality was satisfied. Median time from calving to first insemination tended to be longer for treated than control cows (83 and $74 \mathrm{~d}$, respectively; hazard ratio $=0.72,95 \% \mathrm{CI}: 0.51$ to $1.02, P=0.07$ ). For the Poisson regression model, treatment, occurrence of twins, and occurrence of milk fever were the variables that remained in the model. The probability of pregnancy risk to the first insemination after calving did not differ between treated and control cows (27.0 and $28.8 \%$, respectively; $\mathrm{RR}=0.92,95 \%$ CI: 0.69 to $1.24, P=0.59)$.

\section{DISCUSSION}

Approximately $50 \%$ of the cows enrolled in the study were excluded from the analysis because of discrepancies between the laboratory and cow-side measurements of serum BHBA, which decreased the power of the study to detect significant differences between treatment groups. The differences between BHBA concentrations measured in blood with the point-ofcare meter and in serum in the diagnostic laboratory were small, and perfect agreement was not expected (Iwersen et al., 2013). Nevertheless, the proportion of cows whose classification relative to the inclusion criterion for the study (BHBA $\geq 1.3 \mathrm{mmol} / \mathrm{L}$ ) changed was unexpected. We maintained the planned case definition for hyperketonemia, based on the laboratory analysis. The same statistical analyses as described above were performed on the full data set before any cows were excluded, and those analyses yielded similar results to those reported here in the reduced data set. Cows excluded from the final analysis were similar to those retained and were balanced between the treatment and control groups and among farms and seasons of calving (Table 1). Therefore, although this loss of data was unexpected and inexplicable, we believe the exclusions did not introduce bias into the final data. Based on the results obtained, we submit that it is very unlikely that the inferences to be drawn from the present study would be different even if the full data were used.

\section{Health}

The purpose of this study was to determine the effect of administering low doses of rbST to cows with hyperketonemia during early lactation on production, reproduction, specific metabolite, and disease incidence. The cumulative incidence of hyperketonemia in the cows screened for this study ranged from 3 to $28 \%$ among the herds, which is within the range suggested by previous reports. A recent study conducted in free-stall herds in New York and Wisconsin reported that peak incidence and prevalence for hyperketonemia occurred at 5 DIM and were $22.3 \%$ and $28.9 \%$, respectively (McArt et al., 2012). A review that summarized recent studies showed a prevalence range of 0 to $71 \%$ among herds (McArt et al., 2013), whereas an older review showed that incidence of hyperketonemia in dairy herds ranged from 8 to $80 \%$ (Duffield, 2000).

Although cows treated with rbST had a lower BCS than control cows, the difference of 0.1 of a BCS unit on a 5 -point scale, which is equivalent to approximately $8 \mathrm{~kg}$ of BW (Schwager-Suter et al., 2001), is neither biologically nor clinically important. If rbST is adminis- 
tered during the phase of negative energy balance, as in the current trial, lipolysis and fat mobilization are promoted, resulting in a decrease in BCS and an increase in NEFA concentrations (Bauman, 1992). Some studies in which cows were treated with rbST before and after calving showed no difference in BCS between treated and control cows (Gulay et al., 2004a,b). Although not measured in the current trial, DMI was not likely different between the treatment and control groups because milk production and BCS were similar between groups. Perhaps the dose $(325 \mathrm{mg})$ and the duration of $\mathrm{rbST}$ treatment in this study ( 2 doses 2 wk apart) were not adequate to stimulate an increase in DMI.

\section{Blood Analytes}

The difference of $0.03 \mathrm{mmol} / \mathrm{L}$ in serum NEFA concentrations between groups is practically and biologically unimportant. In the current study, resolution of hyperketonemia did not differ between groups. When Gulay et al. (2007) combined data from 3 studies in which cows were treated with $143 \mathrm{mg}$ of rbST from 21 $\mathrm{d}$ before calving to $42 \mathrm{DIM}$, they found a reduction in the incidence of hyperketonemia in rbST-treated cows. This finding was speculated to be a result of improvement of DMI in treated cows. Another study also found a reduction in hyperketonemia in cows treated with different doses of rbST in the previous lactation (Lean et al., 1994). It could be that the longer duration of rbST treatments in these studies resulted in the lower incidence of hyperketonemia compared with the treatments administered in the current trial.

Bovine somatotropin can influence glucose metabolism in different ways: enhancing liver gluconeogenesis, reducing glucose oxidation, and increasing glycogen mobilization (Peel and Bauman, 1987). All of these actions combined result in an increase of available glucose. Serum glucose concentrations, measured weekly, were similar between treated and control cows. It is possible that only 2 treatments of rbST given to cows with hyperketonemia was insufficient to cause an increase in blood glucose. However, many studies have found no differences in blood glucose between rbST-treated and control cows (Eppard et al., 1996; Gulay et al., 2003, 2004b).

Higher AST for treated cows is consistent with the finding of higher NEFA in treated cows. However, the difference in AST concentrations between groups was very small and practically unimportant.

\section{Milk Production}

The effects of hyperketonemia in the first week of lactation are measurable up to the third DHIA test of lactation at approximately 90 DIM (Duffield et al., 2009). Although the effect of a single injection of 325 mg of sometribove zinc on milk yield is expected to last no more than $14 \mathrm{~d}$, we hypothesized that therapy of hyperketonemia might have carryover effects beyond the time of the direct effects of treatment. Treated and control cows did not differ in overall milk production to 98 DIM or specifically in the 2 biweekly periods immediately following each treatment. One reason that could explain a lack of increased milk-production response to rbST administered early in lactation is that somatotropin mediates its function on the mammary gland through IGF-I (Bauman, 1992), and the increase in somatotropin following calving corresponds to a decrease in IGF-I (Radcliff et al., 2003), which coincides with the time treatments were initiated in the current trial. On the other hand, authors of a meta-analysis concluded that cows treated with rbST before 35 DIM had an increase of $2.6 \pm 0.6 \mathrm{~kg} / \mathrm{d}$ in milk production and $3.2 \pm 0.7 \mathrm{~kg} / \mathrm{d}$ of $3.5 \%$ FCM until 90 DIM (Carriquiry et al., 2008). Cows in the current trial were hyperketonemic and could be expected to have a higher fat content in milk (Duffield et al., 1997), although milk composition data were not available in the present study. However, cows with hyperketonemia would also be expected to have lower milk yield in early lactation than nonhyperketonemic cows (Duffield et al., 2009). The lack of meaningful effects of treatment on the metabolites measured in the present study indicates that the dose and frequency of rbST used here did not support changes that would lead to improved milk yield in this subpopulation of hyperketonemic cows, which by definition have impaired metabolic function.

\section{Reproductive Performance}

Administering rbST in early lactation to cows with hyperketonemia did not improve reproductive performance at first insemination in the current trial. Hyperketonemia in early lactation decreased pregnancy at first insemination at approximately 75 DIM (Walsh et al., 2007), so our hypothesis was that if rbST mitigated the effects of hyperketonemia, improved pregnancy to first insemination might follow. Positive effects of rbST on reproductive performance were previously documented when it was administered nearer the time of insemination. A recent study showed an increase in ovulation to the first $\mathrm{GnRH}$ treatment in the Ovsynch protocol but not the second treatment, when cows were treated 6 times with $500 \mathrm{mg}$ of rbST $10 \mathrm{~d}$ apart starting after 60 DIM (Rivera et al., 2010). Another study showed an enhancement in cleavage in bovine embryos in vitro at $3 \mathrm{~d}$ after fertilization when bovine somatotropin was added to the maturation media (Moreira et al., 2002). 
Differences between the current study and the abovementioned studies include the timing, frequency, and dose of rbST used and the longer time between the last rbST treatment and insemination.

\section{CONCLUSIONS}

Results of the current study indicate that rbST treatment (325 mg, administered twice, $14 \mathrm{~d}$ apart) in hyperketonemic cows did not resolve the condition or enhance health or performance. Although some blood metabolites were slightly different for treated than control cows, these differences were not clinically or biologically important. Although exclusion of a substantial proportion of data to respect the inclusion criterion of the study design reduced the statistical power of this study, based on the results obtained, the conclusions would likely be similar with a larger sample. Based on the current results, we do not recommend use of $325 \mathrm{mg}$ of rbST to treat cows with hyperketonemia.

\section{ACKNOWLEDGMENTS}

The authors acknowledge Elanco Animal Health (Greenfield, IN) for funding this study, and the Animal Health Laboratory at the University of Guelph (Ontario, Canada) for analyzing blood samples. The authors are grateful for the assistance provided by farm staff and technical staff at Perry Veterinary Clinic in Perry, New York, and for their participation in this study.

\section{REFERENCES}

Andersson, L. 1988. Subclinical ketosis in dairy cows. Vet. Clin. North Am. Food Anim. Pract. 4:233-251.

Bauman, D. E. 1992. Bovine somatotropin: Review of an emerging animal technology. J. Dairy Sci. 75:3432-3451.

Bauman, D. E., F. R. Dunshea, Y. R. Boisclair, M. A. McGuire, D. M. Harris, and K. L. Houseknecht. 1989. Regulation of nutrient partitioning: Homeostasis, homeorhesis and exogenous somatotropin. Pages 306-323 in 7th Int. Conf. Prod. Dis. Farm Anim. Cornell Univ., Ithaca, NY.

Carriquiry, M., W. J. Weber, and B. A. Crooker. 2008. Administration of bovine somatotropin in early lactation: A meta-analysis of production responses by multiparous Holstein cows. J. Dairy Sci. 91:2641-2652.

Dohoo, I., W. Martin, and H. Stryhn. 2009. Veterinary Epidemiologic Research. 2nd ed. VER Inc., Charlottetown, PEI, Canada.

Duffield, T. F. 2000. Subclinical ketosis in lactating dairy cattle. Vet. Clin. North Am. Food Anim. Pract. 16:231-253.

Duffield, T. F., D. F. Kelton, K. E. Leslie, K. D. Lissemore, and J. H. Lumsden. 1997. Use of test day milk fat and milk protein to detect subclinical ketosis in dairy cattle in Ontario. Can. Vet. J. 38:713-718.

Duffield, T. F., K. D. Lissemore, B. W. McBride, and K. E. Leslie. 2009. Impact of hyperketonemia in early lactation dairy cows on health and production. J. Dairy Sci. 92:571-580.

Duffield, T. F., D. Sandals, K. E. Leslie, K. Lissemore, B. W. McBride, J. H. Lumsden, P. Dick, and R. Bagg. 1998. Efficacy of monensin for the prevention of subclinical ketosis in lactating dairy cows. J. Dairy Sci. 81:2866-2873.

Eppard, P. J., J. J. Veenhuizen, W. J. Cole, P. G. Comens-Keller, G. F. Hartnell, R. L. Hintz, L. Munyakazi, P. K. Olsson, R. H. Sorbet, T. C. White, C. A. Baile, R. J. Collier, J. P. Goff, and R. L. Horst. 1996. Effect of bovine somatotropin administered to periparturient dairy cows on the incidence of metabolic disease. J. Dairy Sci. 79:2170-2181.

Fetrow, J. P., J. W. Pankowski, J. L. Vicini, and T. R. Ames. 1999. Use of bovine somatotropin at the time of surgery for left displacement of the abomasum in dairy cows. Minnesota Dairy Practitioners Study Group. J. Am. Vet. Med. Assoc. 214:529-531.

Gordon, J. L., S. J. Leblanc, and T. F. Duffield. 2013. Ketosis treatment in lactating dairy cattle. Vet. Clin. North Am. Food Anim. Pract. 29:433-445.

Gulay, M. S., A. N. Garcia, M. J. Hayen, C. J. Wilcox, and H. H. Head. 2004a. Responses of Holstein cows to different bovine somatotropin (bST) treatments during the transition period and early lactation. Asian-australas. J. Anim. Sci. 17:784-793.

Gulay, M. S., A. Garcia-Gavidia, C. J. Wilcox, M. J. Hayen, and H. H. Head. 2000. Physiological responses of Holstein cows to bovine somatotropin (bST) treatments during the transition period. J. Dairy Sci. 83(Suppl. 1):219. (Abstr.)

Gulay, M. S., M. J. Hayen, M. Liboni, T. I. Belloso, C. J. Wilcox, and H. H. Head. 2004b. Low doses of bovine somatotropin during the transition period and early lactation improves milk yield, efficiency of production, and other physiological responses of Holstein cows. J. Dairy Sci. 87:948-960.

Gulay, M. S., M. J. Hayen, L. C. Teixeira, C. J. Wilcox, and H. H. Head. 2003. Responses of Holstein cows to a low dose of somatotropin (bST) prepartum and postpartum. J. Dairy Sci. 86:31953205.

Gulay, M. S., M. Liboni, M. J. Hayen, and H. H. Head. 2007. Supplementing Holstein cows with low doses of bovine somatotropin prepartum and postpartum reduces calving-related diseases. J. Dairy Sci. 90:5439-5445.

Iwersen, M., D. Klein-Jobstl, M. Pichler, L. Roland, B. Fidlschuster, I. Schwendenwein, and M. Drillich. 2013. Comparison of 2 electronic cowside tests to detect subclinical ketosis in dairy cows and the influence of the temperature and type of blood sample on the test results. J. Dairy Sci. 96:7719-7730.

Kelton, D. F., K. D. Lissemore, and R. E. Martin. 1998. Recommendations for recording and calculating the incidence of selected clinical diseases of dairy cattle. J. Dairy Sci. 81:2502-2509.

Lean, I. J., M. L. Bruss, H. F. Troutt, J. C. Galland, T. B. Farver, J. Rostami, C. A. Holmberg, and L. D. Weaver. 1994. Bovine ketosis and somatotrophin: Risk factors for ketosis and effects of ketosis on health and production. Res. Vet. Sci. 57:200-209.

LeBlanc, S. 2010. Monitoring metabolic health of dairy cattle in the transition period. J. Reprod. Dev. 56(Suppl.):S29-S35.

McArt, J. A., D. V. Nydam, and G. R. Oetzel. 2012. Epidemiology of subclinical ketosis in early lactation dairy cattle. J. Dairy Sci. 95:5056-5066.

McArt, J. A., D. V. Nydam, G. R. Oetzel, T. R. Overton, and P. A. Ospina. 2013. Elevated non-esterified fatty acids and betahydroxybutyrate and their association with transition dairy cow performance. Vet. J. 198:560-570.

McArt, J. A., D. V. Nydam, P. A. Ospina, and G. R. Oetzel. 2011. A field trial on the effect of propylene glycol on milk yield and resolution of ketosis in fresh cows diagnosed with subclinical ketosis. J. Dairy Sci. 94:6011-6020.

Moreira, F., F. F. Paula-Lopes, P. J. Hansen, L. Badinga, and W. W. Thatcher. 2002. Effects of growth hormone and insulin-like growth factor-I on development of in vitro derived bovine embryos. Theriogenology 57:895-907.

Ospina, P. A., D. V. Nydam, and T. J. DiCiccio. 2012. Technical note: The risk ratio, an alternative to the odds ratio for estimating the association between multiple risk factors and a dichotomous outcome. J. Dairy Sci. 95:2576-2584.

Ospina, P. A., D. V. Nydam, T. Stokol, and T. R. Overton. 2010. Associations of elevated nonesterified fatty acids and beta-hy- 
droxybutyrate concentrations with early lactation reproductive performance and milk production in transition dairy cattle in the northeastern United States. J. Dairy Sci. 93:1596-1603.

Peel, C. J., and D. E. Bauman. 1987. Somatotropin and lactation. J. Dairy Sci. 70:474-486.

Putnam, D. E., G. A. Varga, and H. M. Dann. 1999. Metabolic and production responses to dietary protein and exogenous somatotropin in late gestation dairy cows. J. Dairy Sci. 82:982-995.

Radcliff, R. P., B. L. McCormack, B. A. Crooker, and M. C. Lucy. 2003. Growth hormone (GH) binding and expression of GH receptor 1A mRNA in hepatic tissue of periparturient dairy cows. J. Dairy Sci. 86:3933-3940.

Rivera, F., C. Narciso, R. Oliveira, R. L. Cerri, A. Correa-Calderon, R. C. Chebel, and J. E. Santos. 2010. Effect of bovine somatotropin
(500 mg) administered at ten-day intervals on ovulatory responses, expression of estrus, and fertility in dairy cows. J. Dairy Sci. 93:1500-1510.

Schwager-Suter, R., C. Stricker, D. Erdin, and N. Künzi. 2001. Quantification of changes in body weight and body condition scores during lactation by modelling individual energy balance and total net energy intake. Anim. Sci. 72:325-334.

Walsh, R. B., J. S. Walton, D. F. Kelton, S. J. LeBlanc, K. E. Leslie, and T. F. Duffield. 2007. The effect of subclinical ketosis in early lactation on reproductive performance of postpartum dairy cows. J. Dairy Sci. 90:2788-2796. 